Old Dominion University

ODU Digital Commons

Biological Sciences Faculty Publications

Biological Sciences

2013

\title{
Heritable Melanism and Parasitic Infection Both Result in Black-Spotted Mosquitofish
}

Lisa Horth

Old Dominion University, Lhorth@odu.edu

David Gauthier

Old Dominion University, dgauthier@odu.edu

Wolfgang Vogelbein

Follow this and additional works at: https://digitalcommons.odu.edu/biology_fac_pubs

Part of the Aquaculture and Fisheries Commons, Biodiversity Commons, Ecology and Evolutionary Biology Commons, and the Environmental Sciences Commons

\section{Repository Citation}

Horth, Lisa; Gauthier, David; and Vogelbein, Wolfgang, "Heritable Melanism and Parasitic Infection Both Result in Black-Spotted Mosquitofish" (2013). Biological Sciences Faculty Publications. 175.

https://digitalcommons.odu.edu/biology_fac_pubs/175

\section{Original Publication Citation}

Horth, L., Gauthier, D., \& Vogelbein, W. (2013). Heritable melanism and parasitic infection both result in black-spotted mosquitofish. Southeastern Naturalist, 12(1), 209-216. doi:10.1656/058.012.0116

This Article is brought to you for free and open access by the Biological Sciences at ODU Digital Commons. It has been accepted for inclusion in Biological Sciences Faculty Publications by an authorized administrator of ODU Digital Commons. For more information, please contact digitalcommons@odu.edu. 


\title{
Heritable Melanism and Parasitic Infection Both Result in Black-Spotted Mosquitofish
}

\author{
Lisa Horth ${ }^{1, *}$, David Gauthier ${ }^{1}$, and Wolfgang Vogelbein ${ }^{2}$
}

\begin{abstract}
Male Gambusia holbrooki (Eastern Mosquitofish) express a heritable pigmentation polymorphism: $\approx 99 \%$ of males are silver, and only $\approx 1 \%$ have a melanic, black-spotted pattern. Sex-linkage, an autosomal modifier, and temperature control the expression of this heritable melanism. In many teleosts, melanin also accumulates around the site of parasitic invasion. We have identified black-spot disease in wild mosquitofish from their native habitat. Here, we demonstrate convergence upon the black-pigmented phenotype through two means: 1) heritable melanism, and 2) melanic spotting on the silver genotype that results from infection with immature encysted trematodes. Females are silver and express greater avoidance of melanic males during mating attempts. The resemblance of the black-spotted pattern of the melanic genotype to that of silver genotype infected with trematodes may affect the fitness of melanic males if females perceive them as diseased. Alternatively, females may shun parasitized silver fish because they resemble the melanic genotype, which is larger and has a larger mating organ.
\end{abstract}

\section{Introduction}

Mosquitofish are live-bearing fish in the family Poeciliidae (Paige and Burr 1991). Gambusia holbrooki Girard (Eastern Mosquitofish) are native to the southeastern United States and share a hybrid zone with G. affinis (S.F. Baird \& Girard) (Western Mosquitofish) around Mobile Bay, AL that extends eastward (Scribner and Avise 1993, Wooten et al. 1988). The wild-type coloration of both species is silver (or olivaceous-gray; Fig. 1A). However, a small percentage of male Eastern Mosquitofish express a rare but heritable melanic, black-spotted pattern that is not found in Western Mosquitofish (Fig. 1B). In this work, we demonstrate that parasitic infection by trematodes produces a black-spotted phenotype that is ostensibly similar to heritable melanism (Fig. 1C).

Eastern Mosquitofish males are considered heterogametic (XY; Angus 1989, Black and Howell 1979), and Western Mosquitofish males are homogametic (WW; Black and Howell 1979, Chen and Ebeling 1968). The absence of a Y chromosome in male Western Mosquitofish may explain why they do not display the heritable melanism identified in Eastern Mosquitofish. Melanism in Eastern Mosquitofish has persistently been documented as very rare, in both scientific publications (McPeek 1991, Myers 1925, Regan 1961, Snelson et al. 1986, Taylor et al. 1996) and museum collection database records (museum collection specimens: CU2533, Naples, FL, 1928; CU2537, Gainesville FL, 1930; CU2539, Everglades, FL, 1930; UMMZ111773, Manatee, FL, 1936). Despite the fact that melanic fish have been recognized since at least the early 1900 s, there are no

\footnotetext{
${ }^{1}$ Department of Biology, Old Dominion University, Norfolk, VA 23529. ${ }^{2}$ Department of Environmental Sciences, School of Marine Science, The College of William and Mary, Gloucester Point, VA 23062. *Corresponding author - 1horth@odu.edu.
} 
published accounts addressing the convergence upon the black-spotted phenotype that results from heritable melanism and parasitic infection by trematodes.

"Black spot" is a prevalent freshwater fish disease (Berra and Au 1978) that may increase in frequency when habitat is degraded (Steedman 1991). Mosquitofish, and many other fish species, develop it as a result of infection by any of several digenetic trematodes (or parasitic flatworms with a complex life cycle; Baker and Bulow 1985; Hoffman 1956, 1967). The name literally refers to the fact that infected fish appear sprinkled with pin-head-sized black spots on the skin where parasites are encysted. Black-spot disease is common in many freshwater habitats of the United States and is thought to retard growth and increase mortality in some species such as Esox Lucius L. (Northern Pike; Harrison and Hadley 1982) and has been shown recently to affect behaviors such as shoaling and individual-level association preferences in Western Mosquitofish (Tobler and Schlupp 2008).

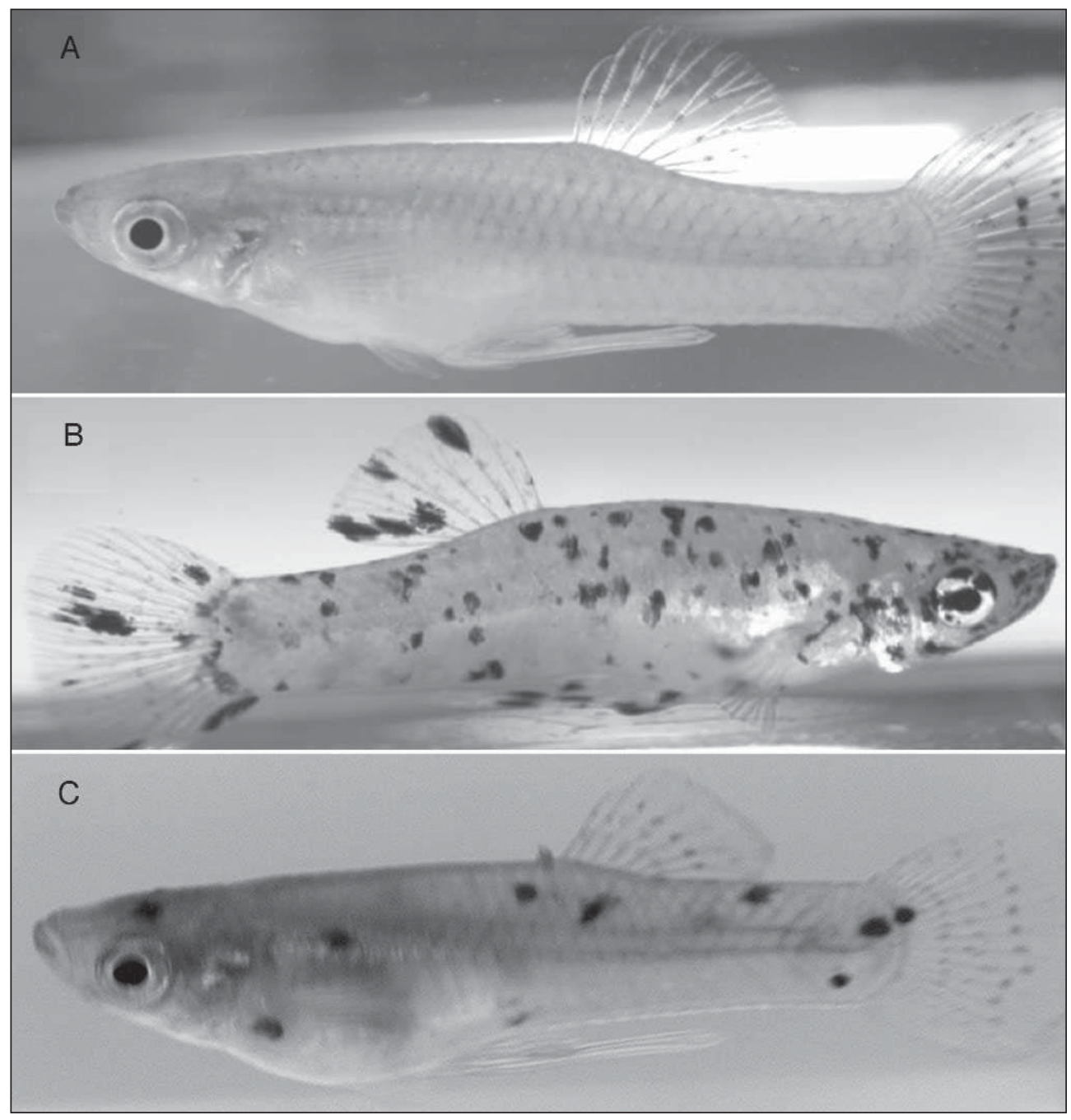

Figure 1. A. The wildtype silver (or olivaceous-gray) male morph of Gambusia holbrooki (Eastern Mosquitofish). B. The melanic spotted male genotype. C. The silver male parasitized by trematodes, demonstrating resemblance to the melanic genotype. 
Here, we report on the convergence upon the black-spotted phenotype in Eastern Mosquitofish that is produced by two different mechanisms: 1) the production of heritable melanic pigmentation, and 2) infection of silver-bodied fish by parasitic trematodes.

\section{Materials and Methods}

To evaluate the inheritance of melanism, virgin F1 juvenile fish were reared in isolation in a $31{ }^{\circ} \mathrm{C}$ laboratory after being born to females from one of three wild populations in Florida (details in Horth 2006). Individual, maturing virgin F1 females were mated to melanic males from the same population. Additionally, two populations were reciprocally crossed. One hundred twenty-five matings yielded over $1000 \mathrm{~F} 2$ individuals that were counted to deduce the inheritance pattern of melanism. F2 fish that did not turn melanic after maturation were moved to an $18^{\circ} \mathrm{C}$ cold room to determine whether the decreased temperature would induce melanic expression. To visually assess melanic deposition in unparasitized fish, ten silver and ten melanic fish were anaesthetized in MS222, and the dermis of these fish was observed under a compound microscope at 100x magnification.

Black-spotted parasitized fish are relatively rare in nature and thus were collected periodically when identified during routine sampling from four populations in Florida (Wakulla Springs and Picnic Pond in Wakulla County, Wacissa River in Jefferson County, and Miami in Dade County) between 1996 and 1999. Approximately 20 fish were collected and maintained in the lab with the expectation of performing behavioral observations on them. It was qualitatively noted that shortly after the invasive plant Hydrilla verticillata (L.f.) Royle (Hydrilla) was mowed in both Wakulla Springs and the Wacissa River, the local mosquitofish population size decreased, fish often had small lacerations, and a greater number of fish appeared diseased.

In 2007, six fish were collected from Miami and Wakulla (3 individuals per population) and dissected for histological evaluation of pigmentation resulting from parasitic invasion. Whole fish were preserved in $10 \%$ neutral buffered formalin, decalcified, and processed for paraffin histology according to standard techniques (Prophet et al. 1994). Thin cross-sections were prepared on a rotary microtome, stained with hematoxylin and eosin, and examined on an Olympus BX70 compound microscope. Digital images were generated with an Olympus DP70 camera.

\section{Results and Discussion}

Inheritance data demonstrated that Y-linkage and an autosomal modifier largely explained the heritable melanic black-spotted pigmentation pattern. Melanic penetrance, or expression, was temperature-sensitive for some populations, and the life-stage at which melanism was expressed varied by population (details in Horth 2006). For example, in fish from Miami, heritable melanic expression was constitutive and initiated just a few days after birth in some fish, and after a few weeks for all fish that expressed melanic pigmentation. In contrast, in fish from Picnic Pond, melanic expression was induced only after $\approx 12$ weeks of exposure to cold $\left(18^{\circ} \mathrm{C}\right)$, which also meant post-maturation. In all cases, once deposited, melanic 
pigmentation was permanent. Many Picnic Pond fish had only a few spots of small size. Parasitized fish tended to look quite similar, and often had several (e.g., 5-10 spots) but not more than 20 spots evident externally, as sites of infection.

Compound microscopic examination of the healthy silver genotype at $100 \mathrm{x}$ magnification revealed small dots of melanin distributed in a patterned fashion across the dermis of the fish. The same basic pattern was also apparent in melanic fish along with fewer, relatively large blotches of melanin distributed in an uneven fashion (not pictured, images available from author upon request). The small dots of pigmentation on both morphs were barely visible by eye, in contrast with the large blotches of melanin on the melanic genotype.

Upon visual inspection, the phenotype of parasitized silver fish often appeared nearly indistinguishable from the melanic genotype. One difference, however, was that the response to the parasite sometimes appeared three dimensional and resulted in slight protrusion on the surface of the fish at some, but not all, sites of invasion. This protrusion did not occur for heritable melanic pigmentation.

Microscopy also demonstrated that both black-spotted phenotypes resulted from the deposition of the inert black pigment melanin into the dermis of the fish. In some parasitized fish, metacercariae (encysted immature parasites) were present in the hypodermis and even underlying the muscle. The parasite-induced phenotype resulted from hyperpigmentation surrounding the granulomatous host cellular response to encysted metacercaria (Noga 2000). This effect was consistent with the fact that trematode metacercariae often elicit melanin deposition in finfishes (Roberts 2001, Roberts and Janovy 2005), which typically results in spots of visible coloration where encysted parasites lie close to the skin surface.

Despite small differences, heritable melanic spots often look the same as parasite-induced spots, especially on fish from temperature-sensitive populations. Heritable melanism occasionally also appears as splotches of black coloration that nearly completely cover a fish. For comparison, when Picnic Pond fish expressed melanic pigmentation in the $18{ }^{\circ} \mathrm{C}$ laboratory, the pigmentation was expressed as small dots, largely resembling the parasitized phenotype. In contrast, when Miami fish expressed melanin in the $31{ }^{\circ} \mathrm{C}$ laboratory, this blotchy pigmentation sometimes occurred over a larger area of the body than was typically covered with parasitism, though there were also fish from Miami that produced only one or a few melanic spots throughout their lifetime.

Histopathological evaluation of parasitized fish demonstrated that the grossly apparent black spots were caused by encysted Neascus metacercariae (Fig. 2). The host response to the parasite was granulomatous in nature, and highly flattened epithelioid cells were seen in the inner layer of the cyst (Fig. 3). In some, but not all parasite-associated granulomas, a layer of chondrocytes existed between the epithelioid layer and a more distal fibrotic layer of the fish. Hyperpigmentation

Figure 3 (opposite page, bottom). A. Neascus metacercarial cyst in the subcutaneous musculature of the Eastern Mosquitofish. Metacercaria (Mc) is present within the cyst, and melanin hyperpigmentation (arrows) is present surrounding the cyst. The epidermis is indicated by (Epi). B. The cyst wall is made up of epithelioid macrophages (arrowheads), chondrocytes $(*)$ and a fibrotic layer. Melanin hyperpigmentation is indicated by arrows. Both scale bars are $50 \mathrm{~mm}$. 


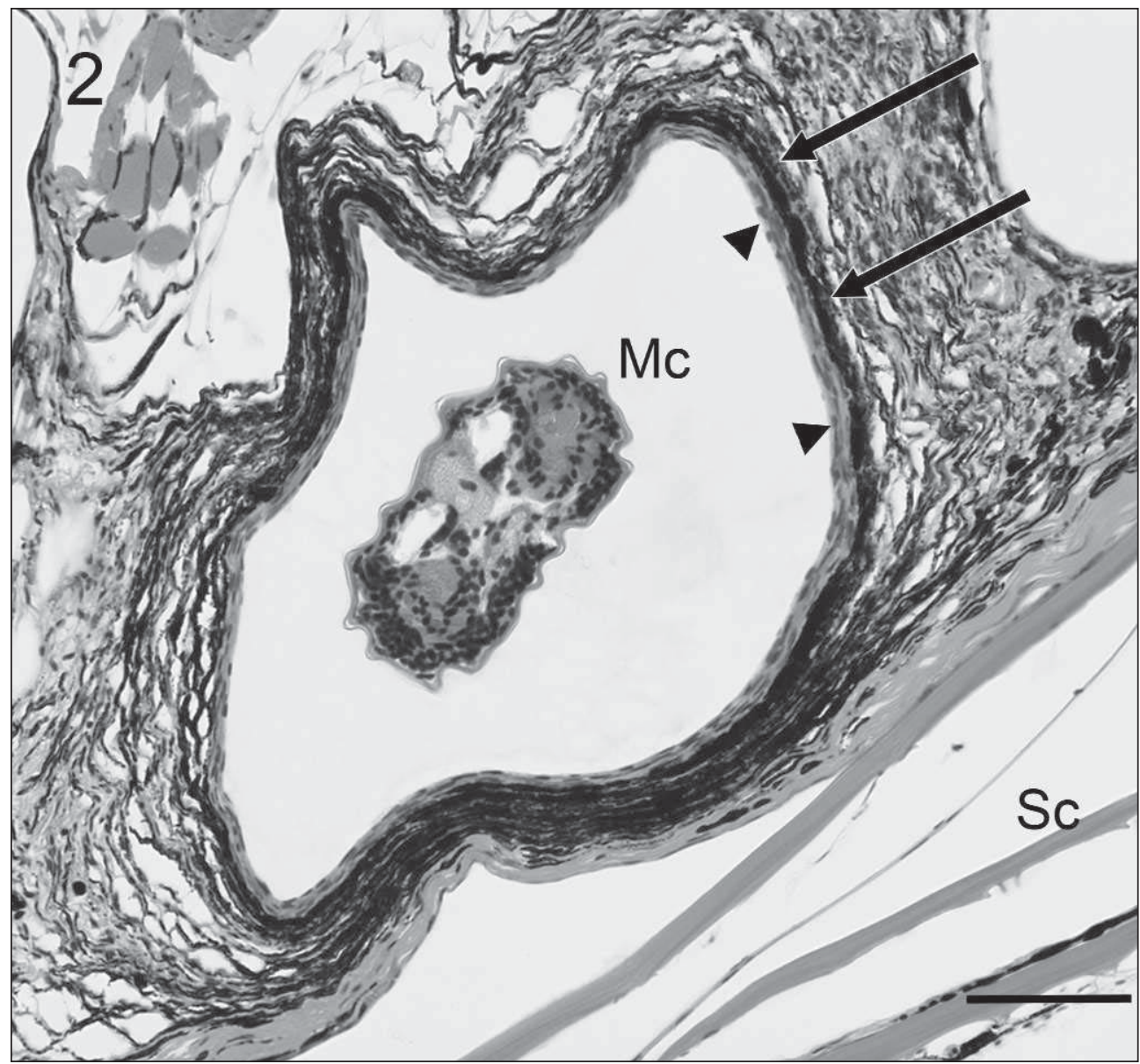

Figure 2. Neascus metacercarial cyst (Mc) in the hypodermis of the Eastern Mosquitofish. Flattened epithelioid cells (arrowheads) line the cyst, and hyperpigmentation (arrows) surrounds the cyst. Scales and scale pockets indicated by (Sc). Scale bar is $50 \mathrm{~mm}$.

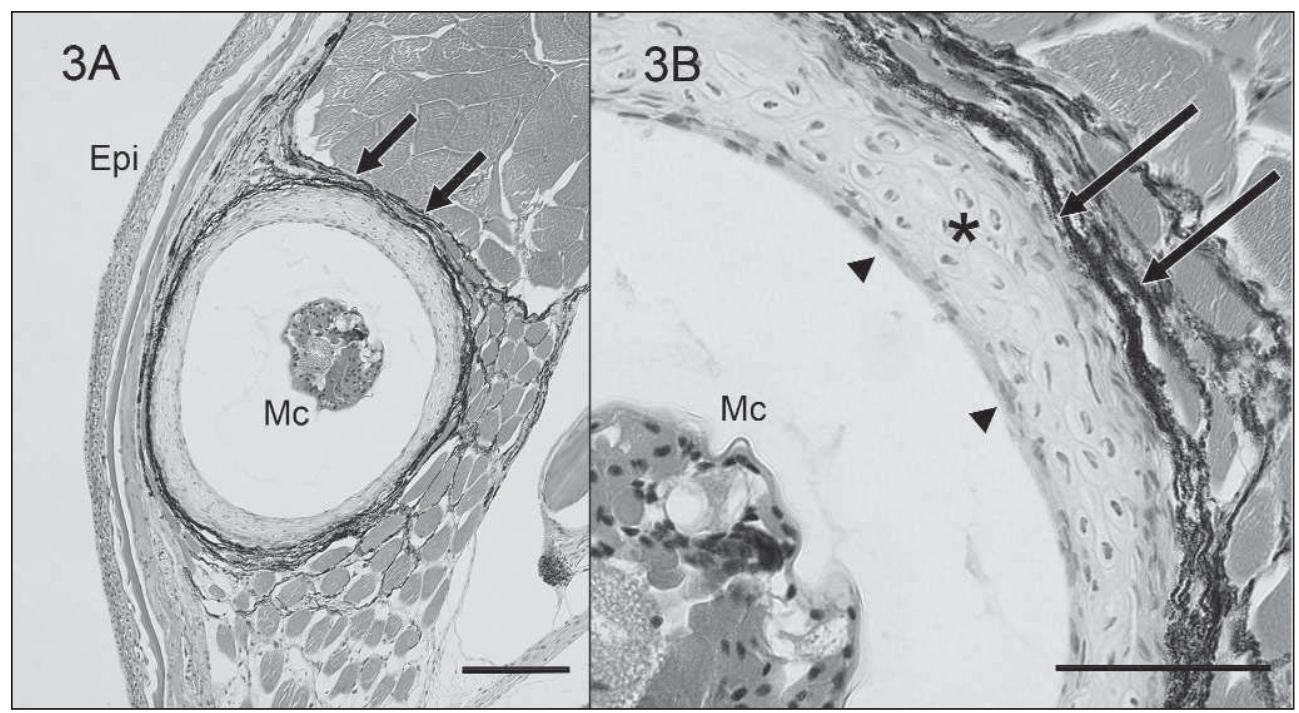


due to melanin was present external to the fibrotic layer, and extended between adjacent myofibers.

A number of strigeoid trematodes cause hyperpigmented spots in the skin of fishes, including Uvulifer ambloplitis (Hughes) (Black Spot Flatworm). This diplostomatid trematode has been reported to infect Western Mosquitofish (Spellman and Johnson 1987). The immature, metacercarial stage of this and related trematodes is called a neascus metacercaria. It is appropriate to refer to these parasites as belonging to genus Neascus until the adult parasite may be properly identified (Roberts and Janovy 2005). Neascus species have a typical digenetic life cycle where motile miracidia penetrate snails and then produce sporocysts. The sporocysts produce mobile cercariae that are released by the snails, penetrate the dermis of fish, and invade the musculature (or other fish tissue). The cercariae then encyst to the metacercarial stage in the fish tissue. When piscivorous birds consume infected fish, they ingest the parasite, which then matures and reproduces in the bird's intestine. The parasite's eggs are then extruded into the water where they hatch into ciliated miracidia.

The genetically based and parasitically induced black-spotted phenotypes both result from the deposition of insoluble melanin in the skin layers of the fish. Thus, it is possible that the presence of a parasitic skin infection in silver males that changes their appearance to black-spotted, could affect the rate at which females approach melanic genotypes because these males are perceived as harboring parasites and could potentially be less fit. For example, Eastern Mosquitofish females were shown to avoid melanic-male mating attempts more than silver-male mating attempts (Horth 2003).

Alternatively, it females may avoid melanic-male mating attempts for reasons unrelated to their phenotypic similarity to parasitized fish. If that was the case, then females may avoid parasitized fish because they resemble melanic genotypes. In fact, melanic males are larger than silver males and additionally have relatively larger mating organs (Horth et al. 2010).

We initiated efforts to study female behavior toward parasitized silver, versus healthy silver and melanic genotypes from all four populations, but parasitized fish often died in the laboratory not long after collection, indicative of low fitness. Given that the melanic mosquitofish genotype has been persistently rare in nature, further investigation is warranted to determine whether females avoid melanic males because they are considered compromised as high-quality mates due to their perceived parasite load. If this were the case, the phenomenon might be generalizable and include other poeciliid species, like Poecilia latipinna (Lesueur) (Sailfin Mollies) and possibly multiple Xiphophorus (swordtail) species (Axelrod and Wishnath 1991) which are also comprised of polymorphic populations with melanic spotted individuals that can be rare. Even unrelated species, like Fundulus chrysotus (Günther) (Golden Topminnow), that harbor rare melanic individuals may experience changes in mate choice since they also host trematode parasites and are sympatric with Eastern Mosquitofish and Sailfin Mollies, where snails and wading birds are prevalent and where habitat degradation has occurred.

Given a choice between parasitized and non-parasitized individuals, Western Mosquitofish preferred not to associate with parasitized conspecifics (Tobler 
and Schlupp 2008). It is noteworthy that one of us (L. Horth) has repeatedly observed parasitized silver males in nature, but not parasitized melanic fish, in over 15 years of collection, despite the fact that on most collection trips, melanic males tended to be dip-netted, measured, and visually scrutinized for assessment of maturation at which time parasitism could have been detected. Whether the rarity of melanic fish with parasites is simply a phenomenon of sampling error (melanic males are very rare), or whether melanin perhaps ironically provides an anti-parasitic property similar to its purported antibacterial properties in other organisms such as birds and insects (Burtt and Ichida 2004, Lambrechts et al. 2004) also remains to be determined.

Overall, the convergence upon the black-spotted phenotype of the melanic genotype and parasitized silver males is a striking natural occurrence. Whether there are fitness consequences for melanic genotypes resembling parasitized fish, or parasitized fish resembling melanic genotypes, also remains to be elucidated. Whether communication regarding parasites is just visual or may also involve olfaction merits additional research since olfactory cues often contribute to conspecific knowledge about parasites (Rivière et al. 2009). Additional work on the effects of parasites and pigmentation polymorphisms may contribute to understanding why some rare genotypes remain rare, and/or how parasitism may alter mating behavior dynamics and female choice.

\section{Acknowledgments}

Thanks to NSF for funding (DEB 1051015 to L. Horth), to R. Bray for assistance with photographs at 100x of the dermis of both fish color morphs, and to two anonymous reviewers who contributed constructive comments.

\section{Literature Cited}

Angus, R. 1989. Inheritance of the melanistic pigmentation in the Eastern Mosquitofish. Journal of Heredity 80:387-392.

Axelrod, H.R., and L. Wischnath. 1991. Swordtails and Platies. TFH Publications, Neptune City, NJ.

Baker, S.C., and F.J. Bulow. 1985. Effects of black-spot disease on the condition of Stonerollers, Campostoma anomalum. American Midland Naturalist 114:198-199.

Berra, T.M., and R.-J. Au. 1978. Incidence of black spot disease in fishes in Cedar Fork Creek, Ohio. Ohio Journal of Science 78:318-22.

Black, D.A., and W.M. Howell. 1979. The North American mosquitofish, Gambusia affinis: A unique case in sex-chromosome evolution. Copeia 1979:509-513.

Burtt, E.H., and J.M. Ichida. 2004. Gloger's rule, feather-degrading bacteria, and color variation among Song Sparrows. The Condor 106:681-686.

Chen, T.R., and A.W. Ebeling. 1968. Karyological evidence of female heterogamety in the Mosquitofish, Gambusia affinis. Copeia 1968:70-75.

Harrison, E.J., and W.F. Hadley. 1982. Possible effects of black-spot disease on Northern Pike. Transactions of the American Fisheries Society 111:106-109.

Hoffman, G.L. 1956. The life cycle of Crassiphiala bulboglossa (Trematoda: Strigeida). Development of the metacercaria and cyst, and effect on the fish hosts. Journal of Parasitology 42:435-444.

Hoffman, G.L. 1967. Parasites of North American Freshwater Fishes. University of California Press, Berkeley, CA. 486 pp. 
Horth, L. 2003. Melanic body-color and aggressive mating behavior are correlated traits in male Mosquitofish (Gambusia holbrooki). Proceedings of the Royal Society of London 270:1033-1040.

Horth, L. 2006. A sex-linked allele, autosomal modifiers, and temperature dependence appear to regulate melanism in male Mosquitofish (Gambusia holbrooki). Journal of Experimental Biology 209:4938-4945.

Horth, L., C. Binckley, R. Wilk, P. Reddy and A. Reddy. 2010. Color, body size, and genitalia size are correlated traits in Eastern Mosquitofish (Gambusia holbrooki). Copeia 2010(2):196-202.

Lambrechts, L., J.M. Vulule, and J.C. Koella. 2004. Genetic correlation between melanization and antibacterial immune responses in a natural population of the malaria vector Anopheles gambiae. Evolution 58:2377-2381.

McPeek, M.A. 1991. Mechanisms of sexual selection operating on body size in the Mosquitofish (Gambusia holbrooki). Behavioral Ecology 3:1-12.

Myers, G.S. 1925. Concerning melanomorphism (spp.) in killifishes. Copeia 137:105-107.

Noga, E.J. 2000. Fish Disease: Diagnosis and Treatment. Iowa State University Press, Ames, IA.

Paige, L.M., and B.M. Burr. 1991. A Field Guide to Freshwater Fishes. Houghton Miflin Company. New York, NY. 417 pp.

Prophet, E.B., B. Mills, J.B. Arrington, and L.H. Sobin. 1994. Laboratory Methods in Histotechnology. Armed Forces Institute of Pathology, $7^{\text {th }}$ Edition. McGraw Hill. New York, NY.

Regan, J.D. 1961. Melanism in the poecillid fish Gambusia affinis (Baird \& Girard). American Midland Naturalist 65:139-143.

Rivière, S., L. Challet, D. Fluegge, M. Spehr, and I. Rodriguez. 2009. Formyl peptide receptor-like proteins are a novel family of vomeronasal chemosensors. Nature 468:574-577.

Roberts, L.S. 2001. Fish Pathology. W.B. Saunders. London, UK.

Roberts, L.S., and J. Janovy, Jr. 2005. Foundations of Parasitology. McGraw Hill, New York, NY.

Scribner, K.T., and J.C. Avise. 1993. Cytonuclear genetic architecture in mosquitofish populations and the possible roles of introgressive hybridization. Molecular Ecology 2:139-149.

Snelson, F.F., R.E. Smith, and M.R. Bolt. 1986. A melanistic female mosquitofish. American Midland Naturalist 115:413-415.

Spellman, S.J., and A.D. Johnson. 1987. In vitro excystment of the Black Spot Trematode, Uvulifer ambloplitis (Trematoda: Diplostomatidae). International Journal for Parasitology 17:897-902.

Steedman, R.J. 1991. Occurrence and environmental correlates of black spot disease in stream fishes near Toronto, Ontario. Transactions of the American Fisheries Society 120:494-499.

Taylor, S.A., E. Burt, G. Hammond, and K. Releya. 1996. Female mosquitofish prefer normally pigmented males to melanistic males. Comparative Psychology 110:260-266.

Tobler, M. and I. Schlupp. 2008. Influence of black spot disease on shoaling behaviour in female Western Mosquitofish, Gambusia affinis (Poeciliidae, Teleostei). Environmental Biology of Fishes 81:29-34.

Wooten, M.C., K.T. Scribner, and M.H. Smith. 1988. Genetic variability and systematics of Gambusia in the southeastern United States. Copeia 1988:283-289. 